\title{
THEORIE EN WERKELIJKHEID \\ BIJ EMISSIES VAN AANDELEN MET RECHT \\ VAN VOORKEUR
}

\author{
door \\ Drs. H. G. Eijgenhuijsen en Drs. G. Rietkerk \\ met medewerking van Drs. $W$. Boomsma
}

\section{Inleiding}

Aan de emissie met recht van voorkeur en meer in het bijzonder aan de theorie van de claimwaarde is in de bedrijfseconomische literatuur hier te lande door verscheidene prominente auteurs aandacht gewijd. Wij noemen slechts de hoogleraren Th. Limperg, J. L. Meij en A. I. Diepenhorst. ${ }^{1}$ ) Voorts mag de dissertatie van Wesselings ${ }^{2}$ ) niet onvermeld blijven.

Naast theoretische beschouwingen omtrent deze emissies zijn op dit terrein nauwelijks resultaten van empirisch onderzoek voorhanden. Met de onderhavige publikatie is gepoogd in dit gemis op bescheiden wijze te voorzien. Getracht is enige in de literatuur gangbare regels, zo men wil theorieën, op hun praktische bruikbaarheid te toetsen.

Alvorens de opzet van het onderzoek bekend te maken, is het wellicht dienstig eerst de meest elementaire achtergronden van de voorkeursemissie te releveren.

Bij een publieke uitgifte van nieuwe aandelen kan een onderscheid worden gemaakt tussen tweeërlei soort emissietechniek. Een vorm die het minst toepassing vindt, is de zgn. „vrije emissie”. Deze techniek spreekt welhaast voor zichzelf: iedereen kan, zonder dat het bezit van claims vereist is, inschrijven. De andere techniek, de emissie met recht van voorkeur, vindt in de praktijk naar verhouding veel meer toepassing. Nu dient men zich van het aantal voorkeursemissies geen overdreven voorstelling te maken; de publieke aandelenuitgifte begint een opvallend verschijnsel te worden ter beurze!

Kenmerkend voor de emissie met recht van voorkeur is dat aan een bepaalde groep personen een preferentie wordt toegekend t.a.v. het verkrijgen der nieuw uit te geven aandelen. De koers van uitgifte van deze aandelen ligt bij een voorkeursemissie op een lager niveau dan de hoogst mogelijke emissiekoers. Doorgaans wordt het voorkeursrecht toegekend aan de oude aandeelhouders, de houders van de reeds uitgegeven aandelen.

Het recht van voorkeur is belichaamd in de claim, een daartoe aangewezen dividendbewijs dat aldus aan zijn oorspronkelijke bestemming wordt onttrokken. Het aantal claims, nodig voor het inschrijven op één nieuw aandeel,

De Vereeniging voor den Effectenhandel en de afdeling Beleggingsadviezen van de Amro Bank zijn wij erkentelijk voor hun bereidwilligheid ons van de nodige gegevens m.b.t. de onderzochte fondsen te voorzien.

De heer J. Bleichrodt danken wij voor zijn hulp bij de verwerking van het onderzockmateriaal.

1) Th. Limperg jr., Bedrijfseconomie; verzameld werk deel 3, Leer van de financiering, Deventer 1966.

J. L. Meij, Leerboek der bedrijfseconomie, deel Il, 's-Gravenhage 1947.

A. I. Diepenhorst, Structuur en politiek, Purmerend 1961.

2) J. H. Wesselings, De claim; beschouwingen over het economische karakter van het claimrecht bij uitgifte van aandelen door naamloze vennootschappen, Amsterdam 1925. 
vloeit voort uit de verhouding tussen het geplaatste aandelenkapitaal en het bedrag der nieuw uit te geven aandelen. De aandeelhouders die niet aan de emissie wensen deel te nemen, kunnen hun claimrecht op de beurs verkopen, bijv. aan hen die wel op de emissie wensen in te schrijven. Aldus ontstaat ter beurze een prijs voor de claims. De beurswaarde van de claim vloeit rechtstreeks voort uit vraag en aanbod en fluctueert derhalve met de marktverhoudingen. Het niveau waarop de claimprijs tijdens de periode van verhandeling ter beurze tot stand komt, wijkt doorgaans af van de zgn. ,theoretische waarde van de claim". Deze laatste kan met behulp van de volgende formule worden berekend:

$$
\mathrm{C}=\frac{\mathrm{K}_{\mathrm{n}}-\mathrm{K}_{\mathrm{e}}}{\mathrm{N}}
$$

$\mathrm{C}=$ Claimwaarde

$\mathrm{K}_{\mathrm{n}}=$ Koers na emissie

$\mathrm{K}_{\mathrm{e}}=$ Emissiekoers

$\mathrm{N}=$ Aantal benodigde claims ter verkrijging van 1 aandeel.

In deze formule zijn de emissiekoers en het benodigd aantal claims gegeven grootheden. De koers na emissie is evenwel een onzekere factor. Wil men met behulp van vorenstaande formule de claimwaarde berekenen, dan zal omtrent de hoogte van deze koers een uitspraak moeten worden gedaan. In dit verband wordt wel een onderscheid gemaakt tussen een drietal ,theorieën" die men kan aanhangen, t.w.:

I. de intrinsieke waarde theorie

Aan deze theorie ligt de veronderstelling ten grondslag dat de koerswaarde van het aandeel gelijk is aan de intrinsieke waarde van de N.V. per aandeel. II. de rentabiliteitswaarde theorie

Word te rentabiliteitswaarde theorie gehanteerd, dan veronderstelt men dat de koers na emissie recht evenredig is met de dividenduitkering.

III. de expansiereserve theorie

De fictie van deze theorie luidt: de waarde van het aandeel is evenredig aan de voor de eerstkomende jaren verwachte winst en het nieuw aan te trekken vermogen zal de winst in de eerstkomende jaren niet vergroten.

Gezien de uiteenlopende onderstellingen die aan de gememoreerde waarderingsmethoden ten grondslag liggen, zal de theoretische koerswaarde van het aandeel na emissie - en derhalve evenzeer de claimwaarde - doorgaans divergeren met de toegepaste theorie.

\section{Opzet van het onderzoek}

Over ecn periode van 11 jaar, t.w. de jaren 1960 tot en met 1970, zijn gegevens verzameld van in totaal 99 emissies van gewone aandelen met recht van voorkeur. Met behulp van het ter beschikking gekomen materiaal is voor alle in het onderzoek betrokken fondsen berekend wat de koers na emissie zou zijn, indien de intrinsieke waarde theorie, de rentabiliteitswaarde theorie of de expansierescrve theorie wordt toegepast. 
Elk van de drie berekende koersen is vervolgens vergeleken met de voor het desbetreffende fonds werkelijk tot stand gekomen koers direkt na emissie. De aldus verkregen procentuele afwijkingen geven reeds een eerste indicatie van de mate waarin de realiteit zich bij elk der theorieën of berekeningswijzen heeft aangesloten.

Met het toepassen van een regressie-analyse is getracht een inzicht te verkrijgen in hoeverre de gevonden theoretische uitkomsten correleren met de voor de nieuwe aandelen eerste werkelijk tot stand gekomen koers na emissie.

Onderzoek van de verschillende spreidingsdiagrammen - waarbij op de ene as de werkelijke eerste koers na emissie en op de andere as resp. de via bovenstaande drie theorieën berekende koers na emissie voorkomt - bracht naar voren dat er bij een werkelijke koers na emissie van ongeveer $600 \%$ een breuk in de regressielijnen optreedt, doordat de werkelijke koers vanaf die waarde de neiging heeft extra vergroot te worden. Ten behoeve van onze berekeningen (en het betrekkelijk geringe aantal fondsen - een twaalftal, in de tabel $^{3}$ ) met een ${ }^{*}$ aangeduid - met een werkelijke koers na emissie van boven de 600\%) is dan ook met deze groep van hoog genoteerde fondsen geen rekening gehouden. De regressie-analyse werd dus toegepast op 87 fondsen.

\section{Tabelindeling en toelichting}

Alvorens de integrale resultaten van het onderzoek te vermelden, is het van belang duidelijk weer te geven hoe de voor het onderzoek relevante cijfers welke in de tabel staan vermeld die is ondergebracht in de appendix bij dit artikel - zijn verkregen en verwerkt. Wij zullen dit doen aan de hand van de gekozen tabelindeling. Deze luidt als volgt:

\begin{tabular}{|c|c|c|}
\hline Kolom & Notatie & Omschrijving \\
\hline 1 & & fonds \\
\hline 2 & & datum emissiebericht \\
\hline 3 & A & geplaatst aandelenkapitaal $\times f 1000,-$ \\
\hline 4 & B & emissiebedrag x $f 1000$ \\
\hline 5 & $\mathrm{~K}_{\mathrm{e}}$ & emissiekoers in $\%$ \\
\hline 6 & $\frac{1}{N}$ & claimverhouding \\
\hline 7 & $\mathrm{D}_{\mathrm{v}}$ & dividend \% vóór emissie \\
\hline 8 & $D_{n}$ & verwacht dividend \% na emissie \\
\hline 9 & $\mathrm{~K}_{\mathrm{v}}^{*}$ & beurskoers vóór emissie in \% (vóór dividendcorrectie) \\
\hline 10 & $\mathrm{~K}_{\mathrm{v}}$ & beurskoers vóór emissie in \% (na dividendcorrectie) \\
\hline 11 & $\mathrm{~K}_{\mathrm{w}}$ & beurskoers na emissie in \% \\
\hline 12 & $\mathrm{~K}_{\mathrm{n} I}$ & $\begin{array}{l}\text { theoretische koers na emissie in } \% \text { volgens intrinsieke } \\
\text { waarde theorie }\end{array}$ \\
\hline 13 & $\mathrm{~K}_{\mathrm{n} ! 1}$ & idem volgens rentabiliteitswaarde theorie \\
\hline
\end{tabular}

3) Zie de appendix bij dit artikel 


$\begin{array}{lll}\text { Kolom } & \text { Notatie } & \text { Omschrijving } \\ 14 & \mathrm{~K}_{\mathrm{n} I I \mathrm{I}} & \text { idem volgens expansiereserve theorie } \\ 15 & & \text { procentuele afwijking van } 12 \text { t.o.v. } 11 \\ 16 & & \text { idem van } 13 \text { t.o.v. } 11 \\ 17 & & \text { idem van } 14 \text { t.o.v. } 11\end{array}$

\section{Toelichting:}

\section{Algemeen (kolom $1 \mathrm{t} / \mathrm{m} \mathrm{6)}$}

Met uitzondering van de datum van het emissiebericht zijn de gegevens met betrekking tot vorengenoemde kolommen gedistilleerd uit de emissieprospectussen. Als datum van het emissiebericht is gekozen de eerste dag dat van het emissieplan via publikatie in de omslag van de officiële prijscourant van de Vereeniging voor den Effectenhandel kennisgeving werd gedaan.

Wat de gekozen fondsen betreft kan worden opgemerkt, dat in het onderzoek slechts dié voorkeursemissies van gewone aandelen zijn betrokken waarin het voorkeursrecht zo zuiver en ongecompliceerd mogelijk tot uiting komt. Buiten het onderzoek zijn gebleven:

- emissies van buitenlandse fondsen.

- emissies van ondernemingen waarvan de aandelen vóór het emissiebericht nog niet op de Amsterdamse effectenbeurs waren genoteerd.

- emissies waarbij mede sprake was van vrije inschrijving.

- emissies waarbij voor de claims, afkomstig van verschillende categorieën aandelen (bijv. gewone aandelen en prefs, resp. aandelen A en B), afzonderlijke prijzen tot stand kwamen.

- emissies met gedeeltelijke storting.

- emissies waarbij een belangrijk pakket aandelen geen voorkeursrecht kreeg toegewezen. Een relatief onbelangrijke post prioriteits- of preferente aandelen vormde geen aanleiding om emissies buiten beschouwing te laten.

- emissies van tegelijkertijd aandelen en (converteerbare) obligaties met recht van voorkeur voor oude aandeelhouders.

- emissies waarbij niet kon worden vastgesteld hoeveel converteerbare obligaties nog vóór de verschijningsdatum van het prospectus waren omgewisseld in aandelen.

\section{Dividend (kolom 7 en 8)}

Ten aanzien van het dividend \% vóór emissie is steeds uitgegaan van een uitkering in contanten, derhalve ook waar sprake was van een dividend naar keuze in aandelen.

Het verwachte dividend \% na emissie moest door interpretatie van de desbetreffende passages in de emissieprospectussen worden vastgesteld. Sommige uitgesproken dividendverwachtingen lieten geen twijfel bestaan. In de gevallen dat de leiding van de onderneming de verwachting uitsprak het dividendpercentage ook na de emissie te kunnen handhaven, werd voor $D_{n}$ hetzelfde percentage genomen als $D_{v}$. Andere formuleringen lieten het niet zo gemakkelijk toe een kwantificering van de dividendverwachting vast te 
stellen. Een uitspraak als: „Hoewel wij ons niet aan voorspellingen over het pas aangevangen boekjaar kunnen wagen, zien wij de toekomst met vertrouwen tegemoet", levert weinig houvast om een gekwantificeerde dividendverwachting te kunnen opstellen. In zulke gevallen is mede aan de hand van het dividendverleden van de betrokken onderneming een gekwantificeerde dividendverwachting over het door de emissie vergrote kapitaal opgesteld.

Waar men verklaarde, dat handhaving van het dividend per aandeel niet mocht worden verwacht, is $D_{n}$ lager vastgesteld dan $D_{v}$. Bij het bepalen van de grootte der dividendverlaging hebben wij ons voornamelijk laten leiden door de teneur van de in het emissieprospectus geuite verwachtingen. In het enkele geval dat in het geheel geen informatie werd verstrekt over de verwachte resultaten, is de dividendverwachting gekwantificeerd aan de hand van het dividendverleden van de desbetreffende N.V.

\section{Beurskoers vóór emissie (kolom 9 en 10)}

Zoals nog nader zal blijken, is voor het calculeren van de theoretische koers der aandelen na emissie bekendheid vereist met de beurskoers vóór emissie. In het onderhavige onderzoek kan aan het hanteren van laatstgenoemde koers de eis worden gesteld, dat hij op een datum tot stand is gekomen die zo dicht mogelijk bij de datum van het emissiebericht ligt. Anderzijds dient niet uit het oog te worden verloren dat de invloed van het emissiebericht nog niet in de koers mag zijn doorgewerkt. Opdat aan beide eisen zo goed mogelijk tegemoet wordt gekomen, is als beurskoers vóór emissie gekozen de gedane koers twee beursdagen vóór de datum van het emissiebericht in de omslag van de officiële prijscourant. Voor actieve fondsen en bij fondsen met een notering in twee perioden is alszodanig het gemiddelde van de gedane koersen gehanteerd. In de slechts exceptionele gevallen dat voor het fonds op die dag een bied- of laatkoers dan wel in het geheel geen koers tot stand kwam, is de gedane notering van één of zo nodig enkele beursdagen eerder gehanteerd.

Op de aldus gevonden beurskoers vóór emissie (kolom 9) diende in de meeste gevallen nog een dividendcorrectie te worden toegepast. De grootte van deze correctie hangt samen met de omvang van het achterstallige dividend op de oude aandelen en de dividendgerechtigdheid van de nieuwe aandelen. De gecorrigeerde koers staat in kolom 10 vermeld.

\section{Beurskoers na emissie (kolom 11)}

Voor elk fonds is als beurskoers na emissie gehanteerd de eerst gedane koers dan wel het gemiddelde van de op één dag eerst gedane koersen - voor de nieuwe aandelen na de inschrijvingsdatum. Op een enkele uitzondering na betrof dit steeds de koers op de beursdag volgend op de inschrijvingsdatum.

Theoretische koers na emissie (kolom 12, 13 en 14)

I. Volgens intrinsieke waarde theorie

De gebezigde formule voor het berekenen van de theoretische koers na emissie volgens de intrinsieke waarde theorie is de volgende: 


$$
K_{\mathrm{n} I}=\frac{N \cdot K_{v}+K_{e}}{N+1}
$$

In woorden: Theoretische koers na emissie $=$ intrinsieke waarde per aandeel na emissie (in \%) = gewogen gemiddelde van beurskoers vóór emissie en emissiekoers.

Een punt waarop gewezen dient te worden in dit verband is, dat de verhouding tussen het aantal geplaatste aandelen vóór emissie en het aantal nieuw uit te geven aandelen niet altijd volkomen overeenstemt met de claimverhouding. In zulke gevallen komt het dikwijls voor, dat ter afronding van een bepaald emissiebedrag het claimrecht verbonden aan één of enkele aandelen niet wordt uitgeoefend. Ook wordt soms het aandelenkapitaal na de emissie afgerond door plaatsing van een aantal aandelen op basis van de beurskoers.

Het gaat in deze gevallen meestal om een relatief zeer gering aantal aandelen en de invloed op de theoretische koers na emissie is bijzonder gering.

\section{Volgens rentabiliteitswaarde theorie}

De theoretische koers na emissie volgens de rentabiliteitswaardeleer is berekend met de volgende formule:

$$
\mathrm{K}_{\mathrm{nII}}=\frac{\mathrm{D}_{\mathrm{n}}}{\mathrm{D}_{\mathrm{v}}} \cdot \mathrm{K}_{\mathrm{v}}
$$

III. Volgens expansiereserve theorie

Met onderstaande formule is de theoretische koers na emissie volgens de expansiereserve theorie berekend:

$$
K_{n I I I}=\frac{A \cdot K_{v}}{A+B}=\frac{\frac{A}{B} \cdot K_{v}}{\frac{A}{B}+1}=\frac{N \cdot K_{v}}{N+1}
$$

\section{Procentuele afwijkingen (kolom 15, 16 en 17)}

De uitkomsten vermeld in de kolommen 12, 13 en 14 zijn vergeleken met de eerste na de emissie voor de nieuwe aandelen tot stand gekomen koers. De procentuele afwijkingen zijn opgenomen in de kolommen 15, 16 en 17 voor resp. de intrinsieke waarde theorie, de rentabiliteitswaarde theorie en de expansiereserve theorie.

De theoretische koersen berekend volgens de rentabiliteitswaarde theorie zijn op een enkele uitzondering na hoger dan de eerste na de emissie genoteerde koers voor de nieuwe aandelen. Daarentegen geven de uitkomsten van de expansiereserve theorie vrijwel steeds lagere koersen te zien dan de eerste beurskoers na emissie. De intrinsieke waarde theorie geeft voor 57 waarnemingen een hogere en voor 30 waarnemingen een lagere theoretische koers 
dan de eerste werkelijk ter beurze opgemaakte koers voor de nieuwe aandelen direkt na de uitgifte.

\section{Resultaten van het onderzoek}

Voor de drie afzonderlijke theorieën pasten wij een enkelvoudige regressieanalyse toe, waarbij de storingstermen multiplicatief werden beschouwd (bij hoog genoteerde fondsen zal uiteraard een grotere afwijking in absolute waarde kunnen voorkomen dan bij laag genoteerde fondsen, hetgeen niet voor de relatieve afwijkingen geldt).

Wij schatten achtereenvolgens de coëfficiënten en exponenten uit de volgende regressievergelijkingen:

$$
\begin{aligned}
& \mathrm{K}_{\mathrm{w}}=\mathrm{K}_{\mathrm{nI}}^{\beta_{1}} \\
& \mathrm{~K}_{\mathrm{w}}=\alpha_{1} \mathrm{~K}_{\mathrm{nI}}^{\gamma_{1}} \\
& \mathrm{~K}_{\mathrm{w}}=\mathrm{K}_{\mathrm{nII}}^{\beta_{2}} \\
& \mathrm{~K}_{\mathrm{w}}=\alpha_{2} \mathrm{~K}_{\mathrm{n} \text { II }}^{\gamma_{2}} \\
& \mathrm{~K}_{\mathrm{w}}=\mathrm{K}_{\mathrm{n} 1 \mathrm{II}}^{\beta_{3}} \\
& \mathrm{~K}_{\mathrm{w}}=\alpha_{3} \mathrm{~K}_{\mathrm{nI1}}^{\gamma_{3}}
\end{aligned}
$$

Opmerking: Voor de regressie-analyse moeten al deze vergelijkingen met een storingsfactor $\mathrm{e}^{\underline{u}}$ worden vermenigvuldigd, waarna de kleinste kwadratenmethode is gehanteerd om de schattingen te verkrijgen.

Voor $K_{w}=K_{n !}^{\beta_{1}}(5)$ berekende de computer $\beta_{1}=1,00$ en voor het kwadraat van de correlatiecoëfficiënt $\mathrm{R}^{2}=0,9676$. Bijna $97 \%$ van de variantie in de werkelijke koers na emissie wordt derhalve door deze formule verklaard.

Wordt een constante $\alpha_{1}$ ingevoerd (vgl. 6), dan blijkt het resultaat er niet door te worden beïnvloed. Het kwadraat van de correlatiecoëfficiënt blijft 0,9676. De betrouwbaarheidsintervallen (er werd steeds een $95 \%$ betrouwbaarheidsinterval aangehouden) zijn dan:

$$
\begin{aligned}
& 0,78<\alpha_{1}<1,21 \\
& 0,96<\gamma_{1}<1,04
\end{aligned}
$$

De puntschattingen worden:

$$
\begin{aligned}
& \alpha_{1}=0,97 \\
& \gamma_{1}=1,00
\end{aligned}
$$

Voor $K_{w}=K_{n ! I}^{\beta_{2}}(7)$ berekende de computer $\beta_{2}=0,97$ en voor de correlatiecoëfficiënnt $R^{2} \stackrel{n=1}{=} 0,9407$.

Het betrouwbaarheidsinterval van $\beta_{2}$ is: $0,965<\beta_{2}<0,975$.

Met behulp van deze formule wordt de variantie van de werkelijke koers na emissie voor $94 \%$ verklaard. 
De rentabiliteitswaarde theorie geeft - zoals ook duidelijk tot uiting komt in kolom 16 van de in de appendix opgenomen tabel - systematisch een te hoge schatting van de koers na emissie. Dit wordt gecorrigeerd door $\beta_{2}=$ 0,97 .

Toevoeging van een multiplicatieve constante (vgl. 8) heeft ook hier geen noemenswaardige invloed. Het kwadraat van de correlatiecoëfficiënt verbetert daardoor weinig tot 0,9419 . De betrouwbaarheidsintervallen zijn dan:

$$
\begin{aligned}
& 0,905<\alpha_{2}<1,6 \\
& 0,89<\gamma_{2}<0,99
\end{aligned}
$$

De puntschattingen zijn:

$$
\begin{aligned}
& \alpha_{2}=1,2 \\
& \gamma_{2}=0,94
\end{aligned}
$$

Voor $K_{w}=K_{\eta_{111}}^{\beta_{3}}$ (formule 9) werd voor het kwadraat van de correlatiecoëfficiënt $\mathrm{R}^{2^{11}}=0,8951$ en een betrouwbaarheidsinterval van $1,02<\beta_{3}<1,04$ berekend. De puntschatting is $\beta_{3}=1,03$.

De correlatiecoëfficiënt voor de expansiereserve theorie is veel slechter dan voor de intrinsieke waarde theorie en de rentabiliteitswaardeleer, hoewel toch nog $90 \%$ van de variantie in de werkelijke koers door deze formule wordt verklaard, maar dit is een laag \% gezien de te verwachten trendmatige correlatie.

Voegen wij een constante toe in deze formule (zie vgl. 10), dan verbetert het resultaat enigszins. Het kwadraat van de correlatiecoëfficiënt wordt dan 0,9306 en de betrouwbaarheidsintervallen:

$$
\begin{aligned}
& 1,9<\alpha_{3}<3,3 \\
& 0,81<\gamma_{3}<0,91
\end{aligned}
$$

De puntschattingen worden:

$$
\begin{aligned}
& \alpha_{3}=2,6 \\
& \gamma_{3}=0,86 .
\end{aligned}
$$

Introductie van de multiplicator $\alpha_{3}$ levert hier dus wèl een significante bijdrage, want $\alpha_{3}>1$.

De koers na emissie volgens de expansiereserve theorie wordt systematisch onderschat $\left.{ }^{4}\right)$. Dit wordt gecorrigeerd door $\beta_{3}=1,03$ of, wanneer een multiplicatieve constante wordt toegevoegd, door $\alpha_{3}=2,6$ en $\gamma_{3}=0,86$. In het laatste geval, dus bij invoering van een multiplicator, blijkt dat in eerste instantie de expansiereserve theorie een overschatting geeft van de koers na emissie en derhalve gecorrigeerd moet worden door $\gamma_{3}$, terwijl er bovendien een schaaleffect zou optreden. Nader onderzoek zou - gezien dit laatste moeten uitwijzen in hoeverre er een nauwkeurig verband bestaat tussen de expansiereserve theorie en de koers na emissie alsmede of dit verband te specificeren valt.

Wij zijn hier niet verder op in gegaan, maar hebben onze aandacht gericht op het nu volgende multipele regressie-model, waarin alle drie theorieën simultaan een rol spelen.

4) Zic ook kolom 17 van de tabel 
De regressievergelijking luidt dan:

$$
K_{w}=K_{n I}^{\beta_{1}} \cdot K_{n I I}^{\beta_{2}} \cdot K_{n I I I}^{\beta_{3}}
$$

waarin $\beta_{1}, \beta_{2}, \beta_{3}$ geschat moeten worden.

Ten behoeve van de analyse dient nog met een residuele term $\mathrm{e}^{\underline{u}}$ vermenigvuldigd te worden, welke wij hier - evenals eerder - verder zullen weglaten. De computer gaf de volgende uitkomsten:

Betrouwbaarheidsintervallen voor $\beta_{1}, \beta_{2}$ en $\beta_{3}$ :

$$
\begin{aligned}
& 0,28<\beta_{1}<0,68 \\
& 0,21<\beta_{2}<0,47 \\
& 0,06<\beta_{3}<0,30
\end{aligned}
$$

De puntschattingen voor $\beta_{1}, \beta_{2}$ en $\beta_{3}$ zijn:

$$
\begin{aligned}
& \beta_{1}=0,40 \\
& \beta_{2}=0,34 \\
& \beta_{3}=0,18
\end{aligned}
$$

Het kwadraat van de correlatiecoëfficiënt $\mathrm{R}^{2}=0,9757$.

Wij mogen hieruit concluderen dat de drie theorieën elk afzonderlijk significant zijn met de grootste bijdrage van $\beta_{1}$ (ten opzichte van $\beta_{3}$ ), d.w.z. de intrinsieke waarde theorie speelt een duidelijk belangrijker rol bij de verklaring van $\mathrm{K}_{\mathrm{w}}$ dan de expansiereserve theorie.

Wordt in de formule een constante $\beta_{0}$ ingevoerd, dus:

$$
\mathrm{K}_{\mathrm{w}}=\beta_{0} \cdot \mathrm{K}_{\mathrm{n} 1}^{\beta_{1}} \cdot \mathrm{K}_{\mathrm{n} ! 1}^{\beta_{2}} \cdot \mathrm{K}_{\mathrm{n} 11 \mathrm{I}}^{\beta_{3}}
$$

dan zijn de betrouwbaarheidsintervallen iets groter voor $\beta_{1}$ en $\beta_{3}$ :

$$
\begin{aligned}
& 0,9<\beta_{0}<1,4 \\
& 0,18<\beta_{1}<0,64 \\
& 0,22<\beta_{2}<0,48 \\
& 0,08<\beta_{3}<0,36
\end{aligned}
$$

De puntschattingen zijn:

$$
\begin{aligned}
& \beta_{0}=1,15 \\
& \beta_{1}=0,41 \\
& \beta_{2}=0,35 \\
& \beta_{3}=0,22
\end{aligned}
$$

Het kwadraat van de correlatiecoëfficiënt $R^{2}=0,9761$.

Het vermeniguuldigen met een constante $\beta_{0}$ is wellicht overbodig, want $\beta_{0}=1$ bevindt zich in het betrouwbaarheidsinterval. De verbetering van de correlatiecoëfficiënt is zeer gering, terwijl bovendien grotere betrouwbaarheidsintervallen ontstaan.

Wij merken met betrekking tot de multipele regressie-analyse nog op, dat de veronderstelling van onafhankelijke verklarende theorieën hier uiteraard 
een fictie is. $K_{n I}$ en $K_{n \text { III }}$ zijn zelfs ten dele hetzelfde (vgl. formule 2 en 4). $\mathrm{Er}$ is dus stellig sprake van multi-collineariteit, welke zijn neerslag vindt in de grootte van de betrouwbaarheidsintervallen.

\section{Slotbeschouwing en conclusies}

De beste verklaring van de koers na emissie wordt gegeven door de formule $K_{w}=K_{n I}^{\beta_{1}} \cdot e^{\underline{\underline{u}}}$, waarbij $\beta_{1}=1$ en voor het kwadraat van de correlatiecoëfficiënt $\mathrm{R}^{2}=0,9676$.

De intrinsieke waarde theorie wordt in de praktijk als regel toegepast om de theoretische waarde van een claim (zie formule 1) te berekenen. Men berekent deze theoretische claimwaarde als een indicatie voor de te verwachten claimwaarde ter beurze. Dat de intrinsieke waarde theorie tot de beste benadering leidt van de koers na emissie zal niet veel verbazing wekken. Men mag immers verwachten, dat de prijsvorming ter beurze wordt beinvloed door de theoretische claimwaarde.

Het opvallende feit doet zich echter voor, dat de regressievergelijking van de rentabiliteitswaarde theorie (vgl. 7) eveneens een redelijke verklaring geeft voor de variantie van de werkelijke koers na emissie. Deze vergelijking blijkt immers $94 \%$ van de variantie in de werkelijke koers na emissie te kunnen verklaren, ofschoon dit hoofdzakelijk bestaat uit het trendeffect.

Uit de resultaten van de toegepaste multipele regressie-analyse is gebleken, dat zowel de intrinsieke waarde theorie als de rentabiliteitswaardeleer een belangrijk gewicht hebben. Men mag derhalve concluderen, dat de veronderstelling van de rentabiliteitswaarde theorie mede een rol speelt in het beleggersgedrag.

Wordt laatstgenoemde theorie uitsluitend beschouwd, dan heeft zij voor de schatting van de te verwachten claimwaarde stellig nut, maar zij dient dan wel gecorrigeerd te worden met een exponent $\beta_{2}$ teneinde systematische invloeden te elimineren. 


\section{Appendix}

Voor de jaren $1960 \mathrm{t} / \mathrm{m} 1970$ worden hieronder de voor het onderzoek relevante cijfers vermeld van in totaal 99 emissies van gewone aandelen met recht van voorkeur. De tabelindeling luidt als volgt:

\begin{tabular}{|c|c|c|}
\hline $\begin{array}{c}\text { Kolom } \\
1\end{array}$ & Notatie & $\begin{array}{l}\text { Omschrijving } \\
\text { fonds }\end{array}$ \\
\hline 2 & & datum emissiebericht \\
\hline 3 & A & geplaatst aandelenkapitaal $\times f 1000,-$ \\
\hline 4 & B & emissiebedrag $x f 1000$ \\
\hline 5 & $\mathrm{~K}_{\mathrm{e}}$ & emissiekoers in \% \\
\hline 6 & $\frac{1}{N}$ & claimverhouding \\
\hline 7 & $\mathrm{D}_{\mathrm{v}}$ & dividend \% vóór emissie \\
\hline 8 & $D_{n}$ & verwacht dividend \% na emissie \\
\hline 9 & $\mathrm{~K}_{\mathrm{v}}^{*}$ & beurskoers vóór emissie in \% (vóór dividendcorrectie) \\
\hline 10 & $\mathrm{~K}_{\mathbf{v}}$ & beurskoers vóór emissie in \% (na dividendcorrectie) \\
\hline 11 & $\mathrm{~K}_{\mathrm{w}}$ & beurskoers na emissie in $\%$ \\
\hline
\end{tabular}

\section{Kolom Notatie Omschrijving}

$12 \quad \mathrm{~K}_{\mathrm{nI}}$ theoretische koers na emissie in \% volgens intrinsieke waarde theorie

$13 \quad \mathrm{~K}_{\mathrm{nII}}$ idem volgens rentabiliteitswaarde theorie

$14 \quad \mathrm{~K}_{\mathrm{n} I \mathrm{II}}$ idem volgens expansiereserve theorie

15

$\left(\frac{\mathrm{K}_{\mathrm{nI}}-\mathrm{K}_{\mathrm{w}}}{\mathrm{K}_{\mathrm{w}}}\right) .100$ procentuele afwijking van 12 t.o,v, 11

16

$\left(\frac{K_{n I I}-K_{w}}{K_{w}}\right) \cdot 100$.idem van 13 t.o.v. 11

17 


\begin{tabular}{|c|c|c|}
\hline 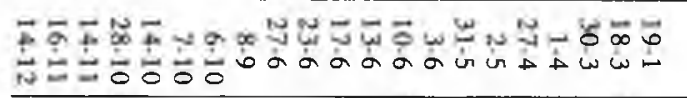 & & $\sim$ \\
\hline 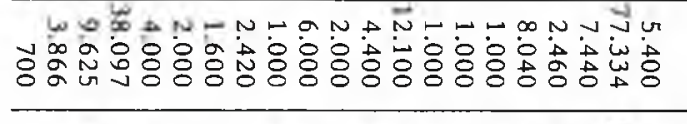 & $>$ & $\omega$ \\
\hline 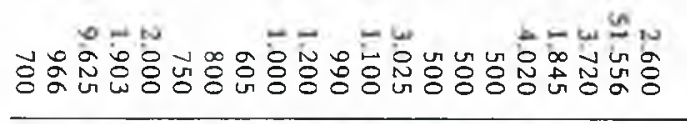 & $\infty$ & 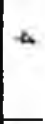 \\
\hline 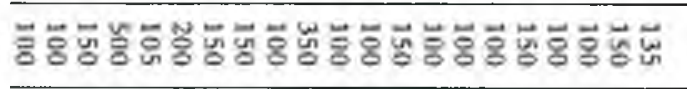 & $a^{7}$ & "s \\
\hline 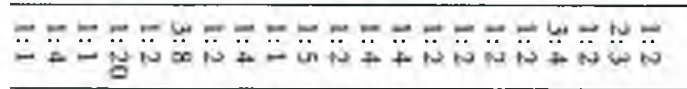 & $z 1-$ & $\bar{\alpha}$ \\
\hline 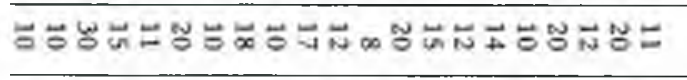 & $=$ & 4 \\
\hline 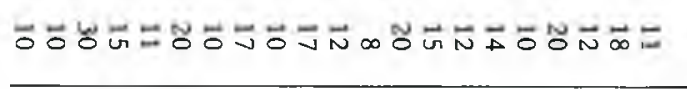 & $=0$ & $\infty$ \\
\hline 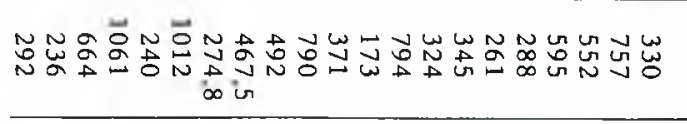 & $e^{x_{*}}$ & 10 \\
\hline 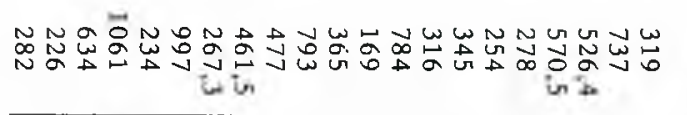 & $x^{x}$ & 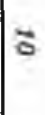 \\
\hline$\underset{j}{\infty}$ & $\underbrace{2}$ & $1=$ \\
\hline 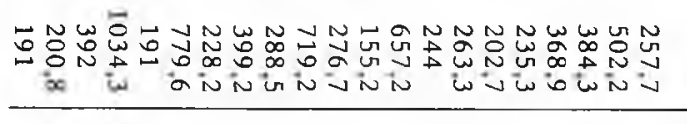 & $z^{2}$ & $\vec{N}$ \\
\hline 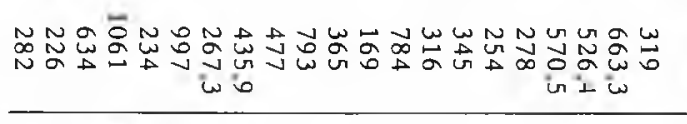 & $\underline{3}$ & $\approx$ \\
\hline 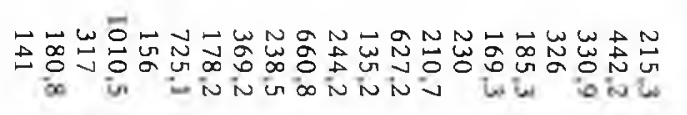 & $E^{2}$ & $\approx$ \\
\hline 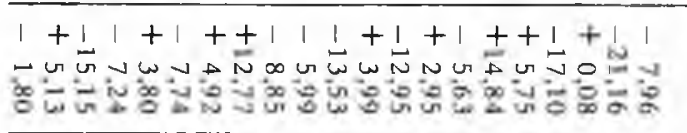 & $\frac{1}{3}$ & $\Rightarrow$ \\
\hline 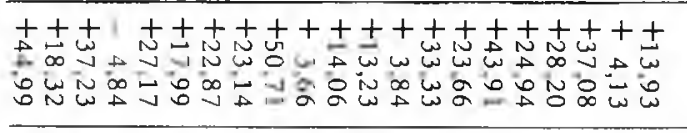 & $\frac{x^{k}}{x^{2}}$ & 2 \\
\hline 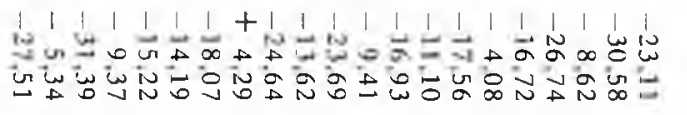 & $\frac{\sqrt{2}}{2 \frac{\pi}{2}}$ & $\bar{z}$ \\
\hline
\end{tabular}




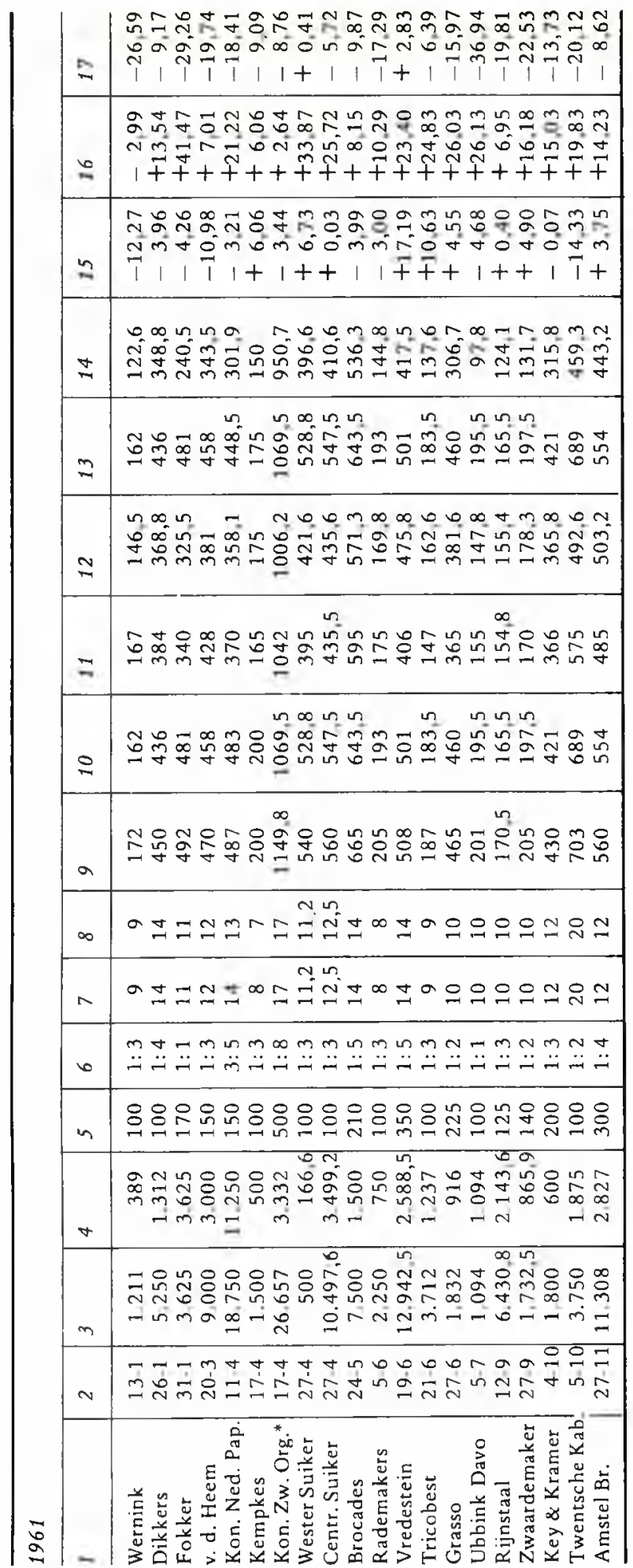

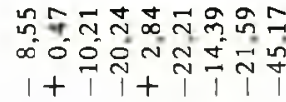

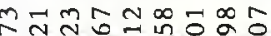
N

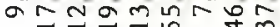
$+\ddot{+}+\ddot{+}+\ddot{+}+\dot{+}+$

ㅇํㅇำ

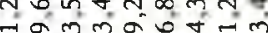
$1+t+t+t+t$

r. ำ

กา เ แก แก

요의 ชิ

$\mathrm{NMNMN \infty}$ N $\mathrm{N}$

$\infty \approx+\infty \infty \pi)$

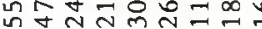

n $m-N+N N 0^{2}$

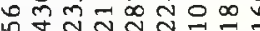

กn แn แn

ㄱ. ํํํำ ๙

⿰纟勺 ก

N in m

뜬듬ำ

때 $\infty$ 넹 0

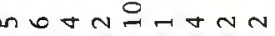
$\ddot{-} \ddot{-} \ddot{-} \ddot{-} \ddot{-} \ddot{-} \ddot{n}$

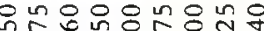
少

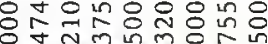
OणNm

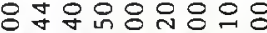
$0 \infty$ m 0 m in แก

NAtum $\tan \frac{\pi}{\mathrm{N}}$

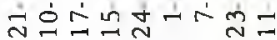

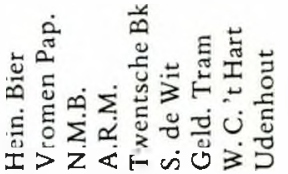




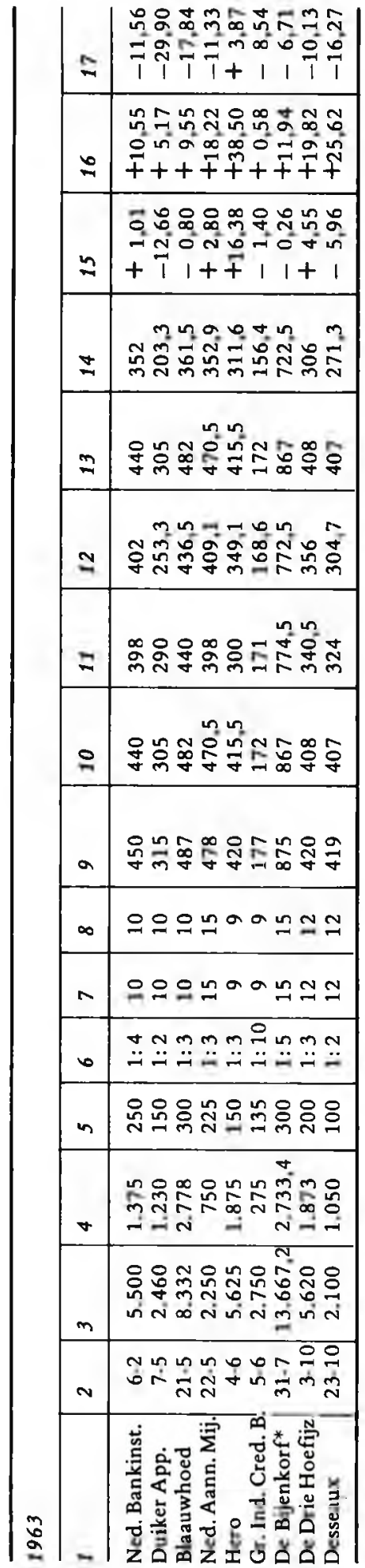

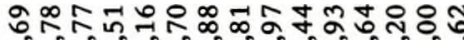

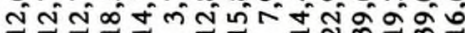

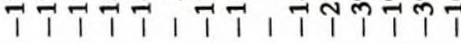

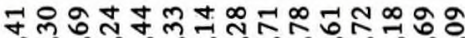

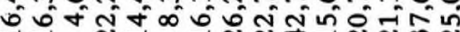

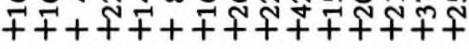

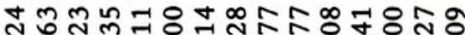

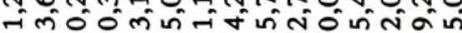
$1+1+++1++\widetilde{+}++++$

$\infty m \infty$ ก 趈 สูล

m ก ก ก ก

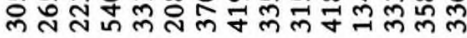

$\infty \infty$ ำ ำ $\infty$ กิ

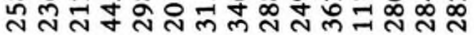

กิ $\infty$ เ

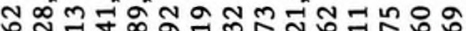
궘ํำ

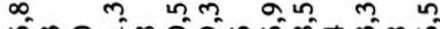

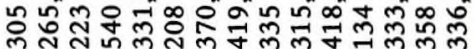
in m in

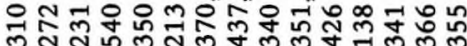
(n)

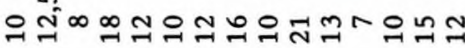

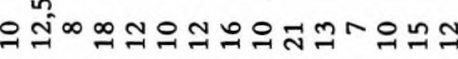

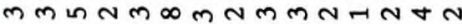

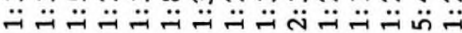

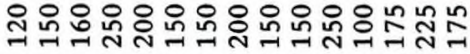

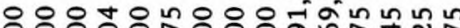

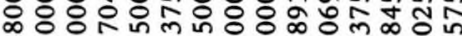
riọ

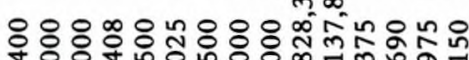

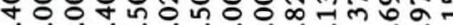

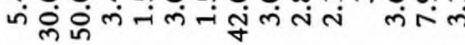

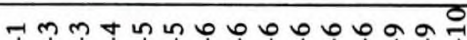
ம்

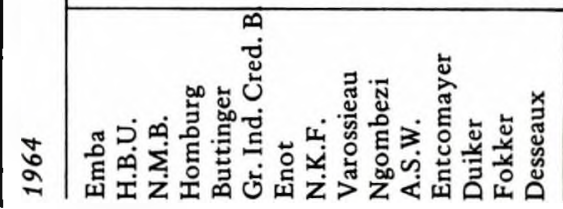




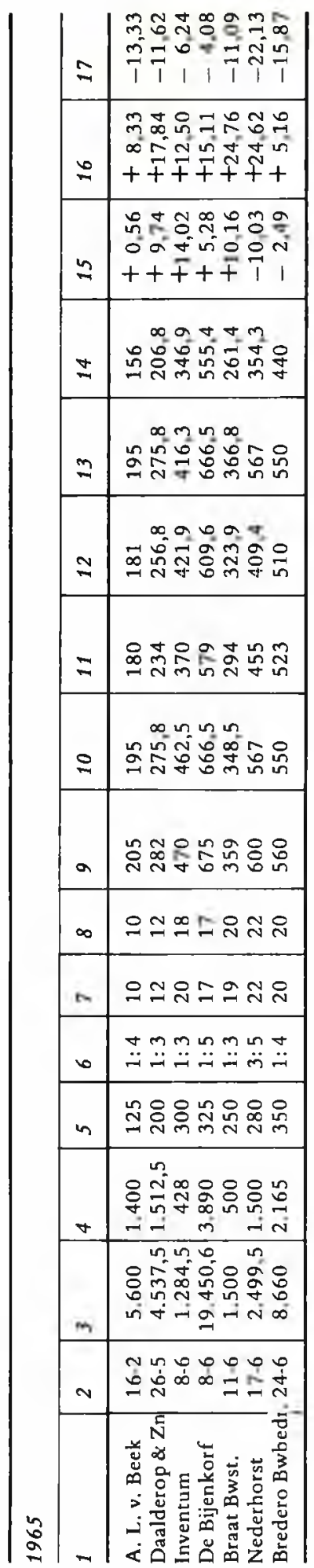

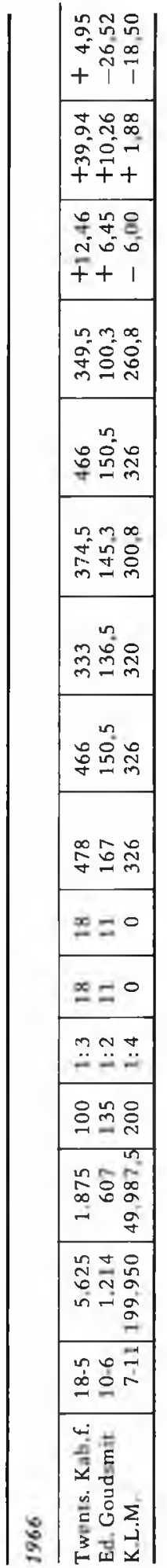

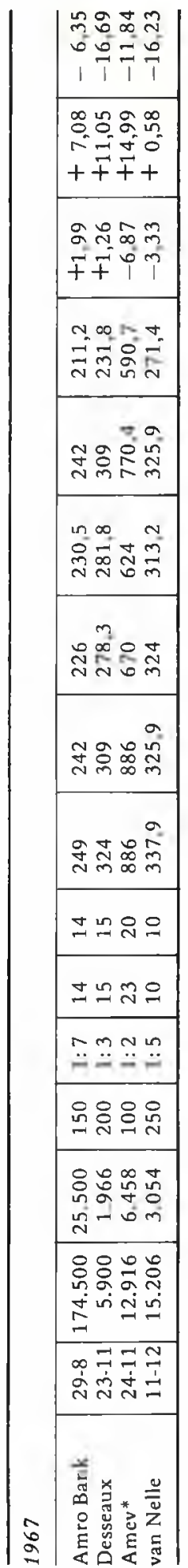




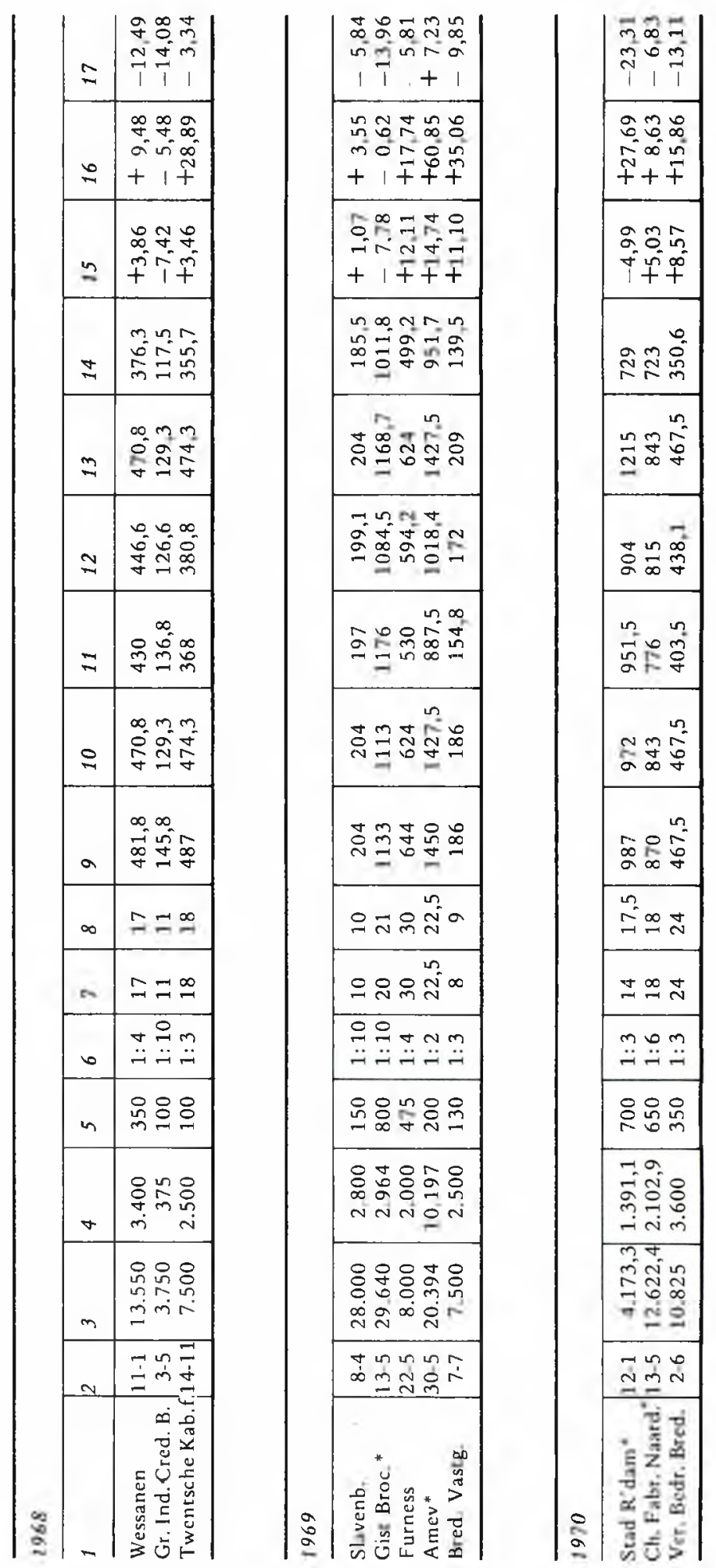

